\title{
Efficiency Rainwater Harvesting at the Roof Campus Buildings
}

\author{
C S Silvia*, M Ikhsan, M Safriani, T P Gusmilia \\ Department of Civil Engineering, Teuku Umar University, West Aceh, Indonesia \\ *Corresponding author E-mail: coetsilvia@utu.ac.id
}

Manuscript received 15 April 2021; revised 1 May 2021; accepted 15 June 2021. Date of publication 3 July 2021

\begin{abstract}
Rainwater harvesting is implemented appropriately by striving to use costs that are quite cheap and efficient, but still has many benefits for meeting clean water needs. In this study, the rainwater harvesting model to be analyzed was using the cistern method. The advantage is that it is easier to apply, the amount of water collected is quite large, and it does not require a large area of land. By implementing a culture of harvesting rainwater, can get several benefits, including reducing runoff which can prevent the UTU campus area from inundation and flooding. The average volume of rainwater that can be harvested using a 5-year return period is 110581.12 liter/day with an average volume of water requirements of 7452.09 liters/day. From the results of the rainwater harvesting analysis, it can be concluded that this method is capable of being applied where the analysis results show that the harvested rainwater can meet the water needs of users on the Teuku Umar University campus. In the future, it will be planning where the excess water stored in the cistern will be channeled into infiltration wells to maintain groundwater sources sustainably.
\end{abstract}

Keywords: rainwater harvesting, cistern method, groundwater, surface runoff.

\section{Introduction}

Rainwater that falls is mostly not utilized and only becomes surface runoff. Indonesia has a potential high rainfall every year to be utilized by the community. One method to be able to collect rainwater is to build a Rainwater Harvesting System (RWHS) [1]. Rainwater Harvesting is an effort to utilize rainwater for daily needs. The basic principle is to drain rainwater that falls from the surface of the roof through a gutter, then it is collected into the reservoir. Rainwater harvesting is implemented by striving to use costs that are quite cheap and efficient, but still have enormous benefits for the needs of clean water for the community [2]. Rainwater harvesting is the collection and storage of rainwater flowing from roofs, parks, roads, etc. This rainwater runoff can be stored or replenished into groundwater (aquifer layer). This technique not only conserves water but can save costs and reduce our impact on the environment, reduce runoff volume and peak flow, thereby reducing flooding. Replenishing groundwater as a solution to the problem of water shortages in the dry season. Some of the basic reasons for a Rain Water Harvesting system include saving water and preventing flooding by slowing runoff and allowing it to soak into the soil [3]. Rainwater harvesting is a simple and low-cost water supply technique that uses the capture and storage of rainwater from roofs of buildings and catchments for domestic, agricultural, industrial and environmental purposes. Although the harvesting of rainwater and runoff has been extensively tested and researched, this practice is not yet widely practiced in the community [4].

Teuku Umar University (UTU) is one of the universities in Meulaboh, West Aceh Regency. The location of the UTU campus is very strategic and serves as a water catchment area, so this area is very suitable to be used as a research location by implementing rainwater harvesting which can be integrated with infiltration wells to the future. In this study, the rainwater harvesting model that will be planned using the cistern method, this method has the same basic concept as the rainwater harvesting method in general, which is to directly

accommodate the rainwater that falls on the roof by going through the rainwater harvesting system components such as gutters, pipes. downspout, first-flush diverter, and water storage unit [10]. Generally, rainwater harvesting technology requires minimal maintenance such as maintenance for tank cleaning and routine inspection of piping systems. Main treatments such as maintenance to remove dirt on the tank, leaves and other collected material. If rainwater is to be used for drinking water, then the inside of the tank must be cleaned first with a bleach solution of about 10 percent and rinsed thoroughly before using the system [11]. For the cistern systems to meet the maximum possible efficiency as desired, the steps that must be carried out in making the cistern are calculating the size of the cistern; choosing the cistern type; cistern placement; creation of a water supply system to the cistern; manufacture of water outlet system for water out of the cistern [12].

The advantage of using the cistern method is that it is easier to apply, the amount of water collected is quite large, and does not require a large area of land. By implementing a culture of harvesting rainwater and absorbing excess water runoff into the ground through infiltration wells, several benefits will be obtained, including increasing the number of groundwater reserves as one of the efforts 
to conserve groundwater sustainably, a cheap source of clean water, and reduce runoff and can prevent the UTU campus land area from inundation and flooding.

\section{Literatur Review}

Research contributions and positions related to rainwater harvesting methods were obtained from another researcher. Tucunan in his research states that rainwater harvesting is a method that can play a role in water management. This method also has another objective, namely to provide a source of clean water and to cope with flooding and excessive runoff. In facing problems regarding access to clean water sources in various regions, the use of rainwater through harvesting rainwater through building roofs needs to be considered as one solution. In addition, this rainwater harvesting technique is very easy to apply in both urban and rural communities, especially since Indonesia is still facing the problem of water scarcity in almost all regions [5]. If the rainwater harvesting system is implemented, this rainwater harvesting system can reduce piped water consumption, the rainwater harvesting system can also save water usage costs and reduce rainfall runoff. So that the storage volume of the rainwater storage system is not too large, it is necessary to have a design suitable for both domestic and non-domestic use of water [6].

Awawdeh stated that Jordan is one of the four poorest countries in the world in terms of water resources. has developed rainwater harvesting as a strategy to address water scarcity since the early 1990s by harvesting rainwater and channeling it to a collection tank, so every home must have a storage tank to collect water. The results of Awawdeh's research on harvesting rainwater from the roofs of buildings at Yarmouk University prove that the great potential for exploiting rainwater storage from rooftops and open areas is very possible. Harvesting rainwater from roofs, roads and parking lots can increase water supply for various purposes helping to address water shortages in Jordan. The results showed that a maximum of $99,000 \mathrm{~m}^{3} /$ year of rainwater can be collected, $37,000 \mathrm{~m}^{3} /$ year from the roof of the building and $62,000 \mathrm{~m}^{3} /$ year from the watertight area, provided that all surfaces are used and all runoff from the surface is collected. The potential for drinking water savings is estimated at 125 to $145 \%$ of the total household water supply. Chemical and biological analysis of the harvested water requires proper water treatment so that nitrate organisms and bacteria can be lost [7].

The biggest environmental challenge facing Jordan today is the scarcity of water supply sources. This scarcity is caused by climatic conditions, such as drought and population pressure. Various ways have been proposed to increase the source of water supply, one of the alternative sources of rainwater is harvesting. The general pattern applied is the storage of water harvested for household needs and the design of rainwater harvesting systems. In addition, harvesting rainwater from the roof of the building by estimating the maximum amount of rainwater that falls is also taken into account so that it can be stored in the reservoir for other needs. The results of Abdulla's research in the rainwater storage system for household water supply in Jordan, show that rainwater can be collected from the roof of residential buildings for a maximum of $15.5 \mathrm{~mm} 3$ / year. The potential to save drinking water is estimated to occur in 12 provinces, ranging from $0.27 \%$ to $19.7 \%$. The analysis of the rainwater samples was tested in the lab and showed that the inorganic compounds from the rainwater are drinkable and generally comply with WHO standards [8]. Awad stated in his research that to improve water resource solutions, apart from harvesting rainwater from the roof of buildings, harvesting from rainwater runoff from sidewalks and footpaths can be used as rainwater storage areas, but it must be designed properly so that it can be collected and connected through a network. pipe and funneled into a reservoir made under the road. The planned design must have a slope on the asphalt road body so that it can drain and collect rainwater [9].
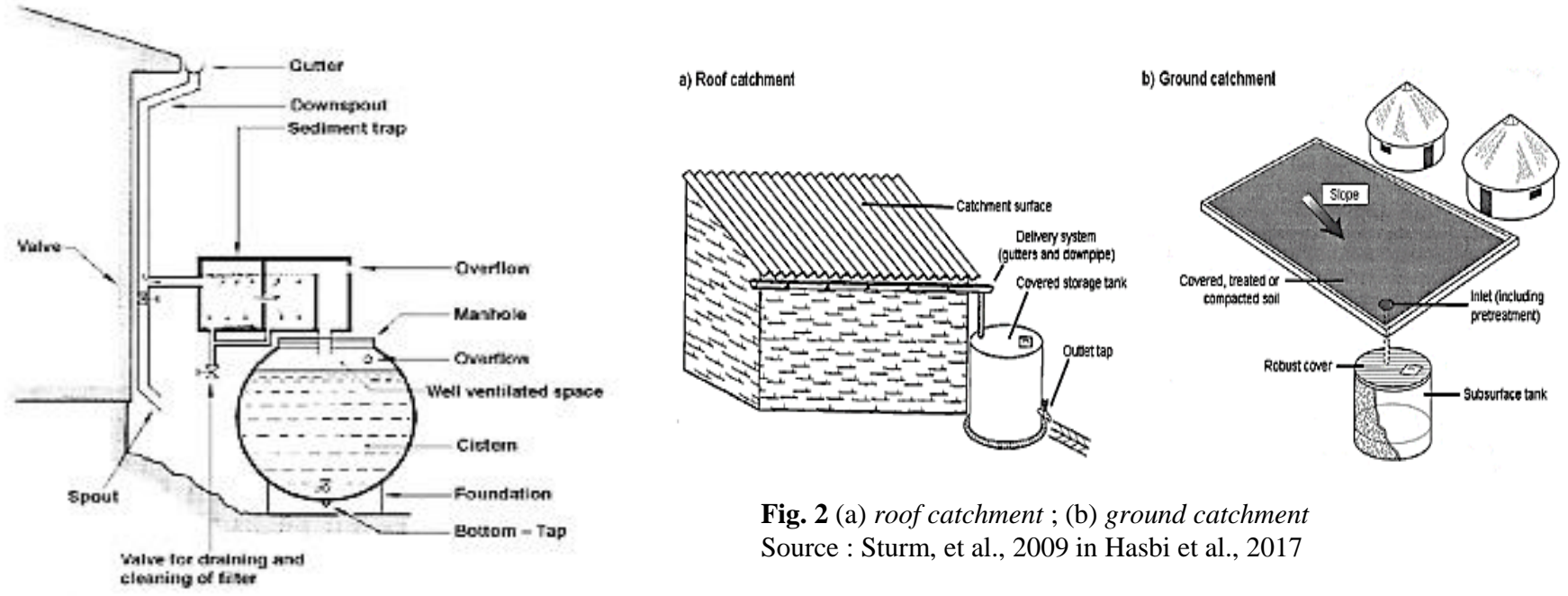

Fig. 2 (a) roof catchment; (b) ground catchment Source : Sturm, et al., 2009 in Hasbi et al., 2017

Fig. 1 Details of the cistern method components Source: Alaska Building Research HCM-0155 in Nazech et al.,

\section{Method}

The location of this research was carried out in the Teuku Umar University (UTU) campus area. The research was conducted for 6 months (September - March 2020) and the type of research was quantitative with survey methods and data analysis. The data that will be used in this research are primary data and secondary data. Primary data obtained from observations in the field in the form of soil samples then tested to obtain soil permeability coefficients and documentation of research activities. Secondary data is supporting data where secondary data collection is carried out with literature studies in the form of books, research journals, rainfall data using 12 years of rain data (2007 to 2018), maps of the Teuku Umar University (UTU) campus, area of rainwater catchment (roof) and the UTU campus land area. As for what is being reviewed are buildings with a roof area that is large enough so that they can produce a large enough volume of water. The placement of the cistern will later consider the location of the adjacent buildings so that the cistern can serve several campus buildings at once. 


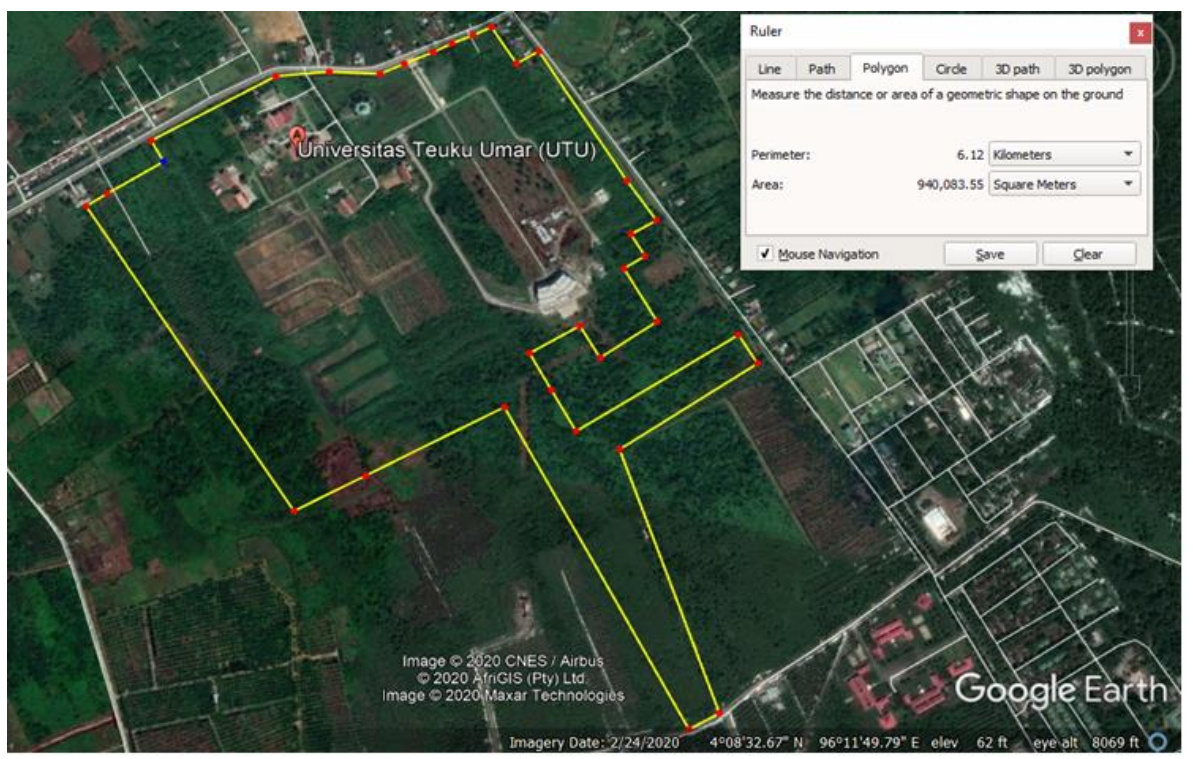

Fig. 3 Research Locations at the UTU Campus

The data processing steps to be carried out in this study follow the research flowchart :

1. Calculating the flood discharge design (Q) of the campus area using the Rational method.

a. Rainfall frequency analysis using Normal, Log-Normal, Gumbel and Pearson III log methods and analysis of rain intensity is needed to calculate the total discharge of rainwater.

b. Rainwater harvesting analysis using the cistern method. Analysis of the supply volume/amount of rainwater that can be harvested by the roof of the Teuku Umar University (UTU) campus building. This method only takes into account the amount of water that can be captured by a catchment by knowing the amount of water demand as a guideline that the volume of water availability must be > than the water requirement which is considered to be the same every day of the year.

Vsupply $=$ Vcistern

2. Analysis of balance and supply-demand cistern method.

a. The calculation method which only calculates the required volume of water is immediately considered as the volume of cisterns that must be provided.

Vdemand $=$ Vcistern

b. Analysis of the total water demand on the Teuku Umar University (UTU) campus. The assumption is that rainfall and catchment area are consistently adequate under the above conditions. For this reason, the development of a calculation model is carried out, namely an approach method in terms of water availability. The needs for daily water use can be seen in the following table.

Table 1: Use of water for daily non-domestic needs

\begin{tabular}{l|c}
\hline \multicolumn{1}{c}{ Water use } & Consumption \\
\hline Bath, wash, toilet & $12,0 \mathrm{Liter} /$ person/day \\
\hline Drink & $2,0 \mathrm{Liter} /$ person/day \\
\hline Wash clothes & $10,7 \mathrm{Liter} /$ person/day \\
\hline House cleanliness & $31,4 \mathrm{Liter} /$ person/day \\
\hline Garden & $11,8 \mathrm{Liter} /$ person/day \\
\hline Wash the vehicle & $21,1 \mathrm{Liter} /$ person/day \\
\hline Ablution & $16,2 \mathrm{Liter} /$ person/day \\
\hline And others & $21,7 \mathrm{Liter} /$ person/day \\
\hline Amount & $126,9 \mathrm{Liter} /$ person/day \\
\hline
\end{tabular}

Source : BPPDU (2006) in Silvia and Safriani, 2018

c. Total cistern volume analysis by considering the balance between water availability and water demand that occurs. The availability of this water comes from the roof while the water requirement is the volume of water needed. Before carrying out the manufacture of the cistern, it is necessary to calculate the volume of rainwater that can be accommodated by the roof, with the assumption that the efficiency of water stored is $75-90 \%$ of the total volume of water that can be stored

$\mathrm{V}=\mathrm{R} \times \mathrm{A} \times \mathrm{k}$

where $: \mathrm{V}=$ Volume of water harvested $\left(\mathrm{m}^{3}\right) ; \mathrm{R}=$ Daily rainfall $(\mathrm{mm}) ; \mathrm{A}=$ Catchment area $\left(\mathrm{m}^{2}\right) ; \mathrm{K}=$ runoff coefficient. 


\section{Result and Discussion}

\subsection{Roof Area Data at Campus UTU}

The application of the rainwater harvesting concept in the Teuku Umar University Campus area is expected to be one of the efforts to conserve groundwater sustainably. To determine the efficiency of using the cistern system, it is necessary to calculate the amount of rainwater capacity that is accommodated on the roof of the campus building as a catchment area. The surface of the rainwater catchment is based on the area of the rainwater catchment in the form of the roofs of the buildings on the UTU campus. The roof area that is reviewed can produce a large enough volume of water. The buildings that are reviewed by researchers on the UTU campus buildings include the Campus of the Faculty of Fisheries, Economics, Social Sciences, Agriculture, Public Health and the Faculty of Engineering. Data on the roof area of each building can be seen in the following table 2:

Tabel 2. Roof Area Data at Campus UTU

\begin{tabular}{|c|c|c|c|}
\hline No & Building & $\begin{array}{c}\text { Roof } \\
\text { area }\left(\mathrm{m}^{2}\right)\end{array}$ & Type of roof \\
\hline 1 & Political and Social Science Faculty Building 1 & 265.963 & a tile roof type \\
\hline 2 & Economic Faculty Building & 290.083 & a tile roof type \\
\hline 3 & Political and Social Science Faculty Building 2 & 290.083 & a tile roof type \\
\hline 4 & Faculty of Agriculture building & 241.200 & a tile roof type \\
\hline 5 & Faculty of Public Health (FKM) Building 1 & 265.320 & a tile roof type \\
\hline 6 & Faculty of Public Health (FKM) Building 2 & 265.320 & a tile roof type \\
\hline 7 & Fishery and Marines Faculty Building & 241.200 & a tile roof type \\
\hline \multirow[t]{2}{*}{8} & Engineering Faculty Building & 265.320 & a tile roof type \\
\hline & Total area of the roof & 2124.490 & \\
\hline
\end{tabular}

The results of the analysis from the table above are the results of calculating the total roof area per faculty which is obtained from the total building type data multiplied by the estimated roof area. From the table above, it can be seen that the total area of the faculty building on the UTU campus is $4752 \mathrm{~m} 2$ and the drainage area is $2124.490 \mathrm{~m} 2$ with a tile roof type.

\subsection{Rainfall Freqency Analysis and Rainfall Intensity}

The analysis of the frequency of rainfall using the normal distribution method, Log-Normal, Gumbel and Log Pearson III. Based on the analysis of statistical parameters, the Pearson III log distribution is used the value of $\mathrm{Cs}=-0.772$ and $\mathrm{Ck}=3,067$ and meets the distribution requirements. From the results of table 3, it can be seen that the design daily rain value (Xt) to be used in this analysis is a 5 -year return period of $41.323 \mathrm{mms}$. Figure 4 is a graph of the correlation between rain intensity and duration of rain, which shows that the daily rainfall intensity for 24 hours in the 2-year return period is $79 \mathrm{~mm} /$ hour, 5 years is $88.3 \mathrm{~mm} /$ hour, 10 years is $93,4 \mathrm{~mm} /$ hour, 25 years is $99 \mathrm{~mm}$ / hour, 50 years is $102,7 \mathrm{~mm} /$ hour and 100 years is $98.8 \mathrm{~mm}$ / hour.

Table 3 Rainfall Plan with Certain Return Periods

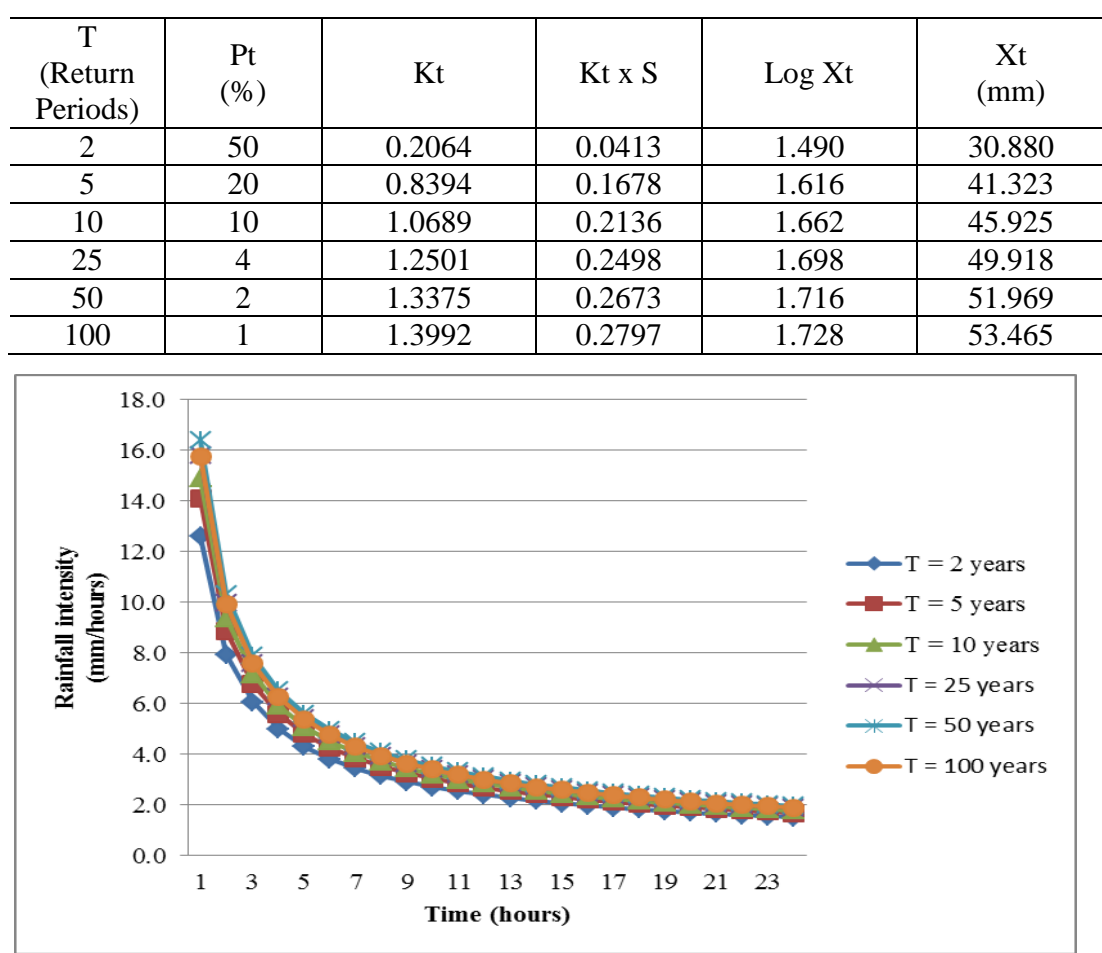

Fig. 4 Analysis of Rainfall Intensity 


\subsection{Volume of Rainwater Harvesting}

The volume of water availability is the volume of rainwater harvesting through the roof of the building on the UTU Campus. The results of field observations and data indicate that the existing type of roof covering is a tile roof, so the runoff coefficient value used based on the reference is 0.85 . By using the equation previously discussed, the volume of rainwater that can be harvested from the roof of the campus building can be seen in the following table 4 :

Table 4: Analysis of Rainwater Harvesting Volume Using Rainfall Design 5 Year Return Period

\begin{tabular}{c|l|c|c|c|c|c}
\hline NO & \multicolumn{1}{|c|}{ Building } & C & I & A & $\begin{array}{c}\text { Rainwater } \\
\text { Harvesting Volume } \\
\left(\mathrm{m}^{3} / \text { hours }\right)\end{array}$ & $\begin{array}{c}\text { Rainwater } \\
\text { Harvesting Volume } \\
(\text { liter/day) }\end{array}$ \\
\hline 1 & Political and Social Science Faculty Building 1 & 0.85 & 0.009 & 265.963 & 0.545 & 13089.666 \\
\hline 2 & Economic Faculty Building & 0.85 & 0.008 & 290.083 & 0.566 & 13595.067 \\
\hline 3 & Political and Social Science Faculty Building 2 & 0.85 & 0.014 & 290.083 & 0.952 & 22851.014 \\
\hline 4 & Faculty of Agriculture building & 0.85 & 0.009 & 241.200 & 0.495 & 11870.919 \\
\hline 5 & Faculty of Public Health (FKM) Building 1 & 0.85 & 0.008 & 265.320 & 0.518 & 12434.513 \\
\hline 6 & Faculty of Public Health (FKM) Building 2 & 0.85 & 0.008 & 265.320 & 0.518 & 12434.513 \\
\hline 7 & Fishery and Marines Faculty Building & 0.85 & 0.009 & 241.200 & 0.495 & 11870.919 \\
\hline 8 & Engineering Faculty Building & 0.85 & 0.008 & 265.320 & 0.518 & 12434.513 \\
\hline & \multicolumn{2}{c}{ Total of Rainwater Harvesting } & & 4.608 & 110581.122 \\
\hline
\end{tabular}

The time for rainwater harvesting to fill the cistern is the ratio between the cistern volume and the rain discharge. The volume of the cistern is planned to be 1100 liters with the rain discharge used with a return period of 5 years which can be seen in Table 5 below.

Table 5: The time for rainwater harvesting to fill the cistern

\begin{tabular}{l|c|c}
\hline \multicolumn{1}{c|}{ Building } & $\begin{array}{c}\text { Volume of cistern } \\
\text { (liter) }\end{array}$ & $\begin{array}{c}\text { The time to fill the } \\
\text { cistern( hours) }\end{array}$ \\
\hline Political and Social Science Faculty Building 1 & 11000 & 20.17 \\
\hline Economic Faculty Building & 11000 & 19.42 \\
\hline Political and Social Science Faculty Building 2 & 11000 & 11.55 \\
\hline Faculty of Agriculture building & 11000 & 22.24 \\
\hline Faculty of Public Health (FKM) Building 1 & 11000 & 21.23 \\
\hline Faculty of Public Health (FKM) Building 2 & 11000 & 21.23 \\
\hline Fishery and Marines Faculty Building & 11000 & 22.24 \\
\hline Engineering Faculty Building & 11000 & 21.23 \\
\hline
\end{tabular}

\subsection{Water Demand Analysis}

The water use activity that will be taken into account at the UTU campus is for ablution with a water use value of 16.2 liters/person/day and other needs of 21.7 liters/person/day. For water demand analysis, it can be seen in the following table. Table 6 explains that the analysis of water needs with a return period of 5 years from all users in the faculty is very sufficient, where the results of the volume of rainwater harvested are greater than water needs. In the future, it will be planned where the excess water stored in the cistern will be channeled into infiltration wells to maintain groundwater sources sustainably.

Table 6. Water Demand Analysis

\begin{tabular}{l|c|c|c|c|c}
\hline \multicolumn{1}{c|}{ Building } & $\begin{array}{c}\text { Total } \\
\text { people }\end{array}$ & $\begin{array}{c}\text { Water consump- } \\
\text { tion (liter/person/ } \\
\text { day) }\end{array}$ & $\begin{array}{c}\text { Water Demand } \\
\text { (liter/person/day) }\end{array}$ & $\begin{array}{c}\text { Rainwater } \\
\text { Harvesting Volume } \\
\text { (liter/day) }\end{array}$ & explanation \\
\hline Political and Social Science Faculty Building 1 & 126 & 37.9 & 4775.4 & 13089.666 & Sufficient \\
\hline Economic Faculty Building & 248 & 37.9 & 9399.2 & 13595.067 & Sufficient \\
\hline Political and Social Science Faculty Building 2 & 351 & 37.9 & 13302.9 & 22851.014 & Sufficient \\
\hline Faculty of Agriculture building & 203 & 37.9 & 7693.7 & 11870.919 & Sufficient \\
\hline Faculty of Public Health (FKM) Building 1 & 137 & 37.9 & 5192.3 & 12434.513 & Sufficient \\
\hline Faculty of Public Health (FKM) Building 2 & 137 & 37.9 & 5192.3 & 12434.513 & Sufficient \\
\hline Fishery and Marines Faculty Building & 126 & 37.9 & 4775.4 & 11870.919 & Sufficient \\
\hline Engineering Faculty Building & 245 & 37.9 & 9285.5 & 12434.513 & Sufficient \\
\hline
\end{tabular}




\section{Conclusion}

Analysis of the water requirements of each building and the volume of water that can be harvested, it can be concluded that rainwater harvesting through the roof of the building is very efficient and can meet the needs of the campus. By channeling the rainwater harvesting to the bathroom using a gravity system, the potential for rainwater harvesting is also very efficient and can reduce the burden of electricity costs from using bore wells. The result showing the average volume of rainwater that can be harvested using a 5-year return period is 110581.12 liter/day with an average volume of water requirements of 7452.09 liters/day. With a return period of 5 years from all users in the faculty is very sufficient, where the results of the volume of rainwater harvested are greater than water needs.

\section{Acknowledgement}

The author would like to thank the Dean of the Faculty of Engineering, Teuku Umar University, Dr. Ir M. Isya, MT, all lecturers and academic staff of the Faculty of Civil Engineering, Teuku Umar University who have allowed the author to conduct this research in the hope of providing input to the campus as initial information about the potential for rainwater harvesting through the roof of the building can be applied in research sites.

\section{References}

[1] A. R. Asnaning, S. Surya, A. E. Saputra, and D. Ahyuni, "Water Conservation with Rainwater Harvesting System in Lampung Province (Case Study in State Polytechnic of Lampung Campus Area),” J. Sci. Appl. Technol., vol. 2, no. 1, pp. 176-182, 2019, doi: $10.35472 / 281453$.

[2] C. S. Silvia and M. Safriani, "Analisis Potensi Pemanenan Air Hujan Dengan Teknik Rainwater Harvesting Untuk Kebutuhan Domestik," vol. 4, no. 1, pp. 62-73, 2018.

[3] S. P. Singh, M. P. Gautam, N. Kumawat, and S. Singh, "Rainwater Harvesting: Aneco Harvesting: Aneco-Friendly Technique of Conserve the Water," Int. J. Trend Sci. Res. Dev. ( IJTSRD ) Pop. Artic., vol. 2, no. 5, pp. 2491-2494.

[4] Joleha, A. Mulyadi, Wawan, and I. Suprayogi, "Application of Rainwater Harvesting Technology to Supply Sustainable Domestic Water,” Int. J. Electr. Energy Power Syst. Eng., vol. 2, no. 1, pp. 10-14, 2019, doi: 10.31258/ijeepse.2.1.10-14.

[5] K. P. Tucunan, P. G. Ariastita, Setiawan, A. M. Navastara, and A. N. Medha, "Rain water harvesting: Barrier, potency and projections. Case study: Keputih, Kejawan and Gebang Putih Surabaya," IOP Conf. Ser. Earth Environ. Sci., vol. 202, no. 1, 2018, doi: 10.1088/1755-1315/202/1/012069.

[6] J. Kartolo and E. Kusumawati, "Feasibility study of rainwater harvesting for domestic use (Case study: West Jakarta rainfall data)," AIP Conf. Proc., vol. 1903, no. November 2017, 2017, doi: 10.1063/1.5011618.

[7] Awawdeh M, Al-Shraideh S, Al-Qudah K, and Jaradat R, "Rainwater harvesting assessment for a small size urban area in Jordan," Int. J. Water Resour. Environ. Eng., vol. 4, no. 12, pp. 415-422, 2012, doi: 10.5897/IJWREE10.025.

[8] F. A. Abdulla and A. W. Al-Shareef, "Roof rainwater harvesting systems for household water supply in Jordan," Desalination, vol. 243, no. 1-3, pp. 195-207, 2009, doi: 10.1016/j.desal.2008.05.013.

[9] A. Awad, F. Al Bajari, and F. Al Adday, "A case study on rainwater harvesting and reuse in Jordan," Int. J. Emerg. Trends Eng. Res., vol. 7, no. 11, pp. 398-402, 2019, doi: 10.30534/ijeter/2019/017112019.

[10] E. K. M. Nazech, T. Saleh, and A. Pauna, "Menentukan Efisiensi " Cistern " Berdasarkan Penggunaan Air Dan Segi Biaya Di Fakultas Teknik Universitas Indonesia," no. 978, pp. 38-48, 2012.

[11] I. U. Mohammed, "Rainwater Harvesting for Water Supply and Integrated Development in Rural and Semi-Urban Areas Article Information Rainwater Harvesting for Water Supply and Integrated Development in Rural and Semi-Urban Areas," Niger. Res. J. Eng. Environ. Sci., vol. 3, no. 1, pp. 287-304, 2018.

[12] T. Y. Susana, "Analisa Pemanfaatan Potensi Air Hujan Dengan Menggunakan Cistern Sebagai Alternatif Sumber Air Pertamanan Pada Gedung Perkantoran Bank Indonesia," Fakultas Teknik Prodi Teknik Sipil, Universitas Indonesia, Depok, Depok, 2012.

[13] M. Hasbi, R. Darma, M. Yamin, M. Nurdin, and M. Rizal, "Rainwater Utilization Management Model Development at the Altitude of Cocoa Plantations Area for the Increase of Cocoa Productivity," Sci. Agric. J., 2017. 